\title{
Effects of Cadmium on Absorption of Copper, Zinc and Iron in Rat Small Intestine in Vitro
}

\author{
(Studies on the Fate of Heavy Metals in Animals. VI)
}

(Received April 18, 1986)

\author{
Yukio TANAKA*1, Ryoichi TANAKA*1 and Takashi KASHIMOTo*2 \\ (*1) Osaka Prefectural Institute of Public Health: 3-69, \\ Nakamichi 1-chome, Higashinari-ku, Osaka, Japan, \\ ${ }^{*}$ Faculty of Pharmaceutical Sciences, Setsunan University: \\ 45-1, Nagaotoge-cho, Hirakata, Osaka, Japan)
}

\begin{abstract}
The effects of cadmium on intestinal absorption of copper, zinc and iron in rat everted intestine were investigated with and without L-cysteine in vitro. Intestinal absorption of copper was inhibited in the cadmium-administered intestine, and was not promoted by L-cysteine. Intestinal absorptions of zinc and iron were clearly inhibited in the cadmium-administered intestine, but were markedly promoted by L-cysteine.

The results of this experiment coincided with those of the previous in vivo experiment, in which copper and iron contents in organs were decreased by oral administration of cadmium as compared with those in controls, and the decrease in iron content was suppressed by the simultaneous administration of L-cysteine with cadmium. As regards copper content, the in vitro results did not coincide with the in vivo findings.
\end{abstract}

Key words: cadmium; cysteine; copper; zinc; iron; intestinal absorption; everted intestine; ceruloplasmin; metallothionein

\section{Introduction}

In the previous studies ${ }^{1), 2)}$, we orally administered cadmium $(\mathrm{Cd})$ alone and $\mathrm{Cd}$ plus $\mathrm{L}$ cysteine (Cys) to rats for 20 consecutive weeks to examine the fates of copper $(\mathrm{Cu})$, zinc $(\mathrm{Zn})$ and iron $(\mathrm{Fe})$ in the rats. The results showed that $\mathrm{Cd}$ had a marked effect on the fates of the three metals: in particular, the $\mathrm{Cu}$ and $\mathrm{Fe}$ contents in organs decreased as compared with the control. Such decreases in $\mathrm{Cu}$ and $\mathrm{Fe}$ contents were suppressed by the simultaneous administration of Cys with $\mathrm{Cd}$. We supposed that the decreases in $\mathrm{Cu}$ and $\mathrm{Fe}$ contents were attributable to the inhibition of intestinal $\mathrm{Cu}$ and $\mathrm{Fe}$ absorption by $\mathrm{Cd}$, on the basis of a comparison with the data after subcutaneous administration of Cd.

To confirm this hypothesis, we carried out the present in vitro study, in which the effects of $\mathrm{Cd}$ on intestinal absorption of $\mathrm{Cu}, \mathrm{Zn}$ and $\mathrm{Fe}$ in rat everted intestine were investigated with and without Cys.

\section{Materials and Methods}

1. Preparation of samples for administration and experimental animals

As reported previously ${ }^{1)}$, samples for administration were prepared, and orally administered to four-week-old Jcl: Sprague Dawley female rats divided into four groups for 4 consecutive weeks.

2. Absorption experiment using everted intestine $^{3), 4)}$

The rats were sacrificed with ether anesthesia at 48 hours after the final administration. The animals had been fasted (but allowed water) for 24 hours before sacrifice. After sacrifice, a section of the small intestine approximately $10 \mathrm{~cm}$ in length was quickly withdrawn and cut away from the duodenal intestine. One side of the cut intestine was rapidly ligated with a silk thread, the intestine being everted with a glass bar. The intestinal contents were washed out with cold physiological saline solution. Into the serosa of the everted intestine, $0.6 \mathrm{ml}$ of a reac- 
Table 1. Effect of Cadmium on Copper Transport and Accumulation in Rat Small Intestine

\begin{tabular}{cccc}
\hline \hline Rat small intestine & Mucosal medium & $\begin{array}{c}\text { Transported } \mathrm{Cu} \\
(\mu \mathrm{g} / \mathrm{ml} \text { serosal medium })\end{array}$ & $\begin{array}{c}\text { Accumulated } \mathrm{Cu} \\
(\mu \mathrm{g} / \mathrm{g} \text { wet tissue })\end{array}$ \\
\hline $\mathrm{Cd}$ & $0.1 \mathrm{mMCu}$ & $0.29 \pm 0.11^{*}$ & $11.7 \pm 3.3^{*}$ \\
Control & $0.1 \mathrm{mMCu}$ & $0.68 \pm 0.25$ & $28.7 \pm 7.0$ \\
\hline $\mathrm{Cd}$ & $0.1 \mathrm{mMCu}+2.0 \mathrm{mM}$ Cys & $0.25 \pm 0.06^{*}$ & $8.6 \pm 1.5^{*}$ \\
Control & $0.1 \mathrm{mMCu}+2.0 \mathrm{mM}$ Cys & $0.86 \pm 0.32$ & $24.8 \pm 4.4$ \\
\hline
\end{tabular}

The everted sac was incubated in mucosal medium at $37^{\circ} \mathrm{C}$ for $60 \mathrm{~min}$.

$\mathrm{Cd}: \mathrm{CdCl}_{2} \cdot 2.5 \mathrm{H}_{2} \mathrm{O}(80 \mathrm{mg} / \mathrm{kg} / \mathrm{day})$ for 4 weeks

Control: Distilled water

Each value is the mean \pm S.D. for 5 intestines.

$* p<0.05$ from Control

tion solution (serosal medium, $30 \mathrm{mM}$ Tris-hydrochloric acid buffer containing $125 \mathrm{mM}$ sodium chloride and $10 \mathrm{mM}$ fructose, $\mathrm{pH}$ 7.4) was injected via an injection syringe with a blunt needle. Immediately after withdrawal of the needle, the intestine was completely ligated with a silk thread. The everted sac was dipped into $10 \mathrm{ml}$ of a reaction solution (mucosal medium) containing $0.1 \mathrm{mM} \mathrm{Cu}\left(\mathrm{CuCl}_{2} \cdot 2 \mathrm{H}_{2} \mathrm{O}\right), 0.2 \mathrm{mM}$ $\mathrm{Zn}\left(\mathrm{ZnSO}_{4} \cdot 7 \mathrm{H}_{2} \mathrm{O}\right)$ or $0.2 \mathrm{mM} \mathrm{Fe}\left(\mathrm{FeSO}_{4} \cdot 7 \mathrm{H}_{2} \mathrm{O}\right)$ and another reaction solution containing each of these three metals plus Cys $(20$ times the molar quantity of metals) in a $25 \mathrm{ml}$ Erlenmeyer flask. Then the sac in the flask was incubated for 60 min at $37^{\circ} \mathrm{C}$ under oxygen gas. After incubation, the everted sac was taken from the flask, dehydrated, and cut open. The reaction solution in the serosa was transferred into a test tube. The contents of metals in the serosal medium were determined by the direct atomic absorption method after dilution of the medium $1 / 5$ with $0.5 \mathrm{~N}$ nitric acid. The contents of metals accumulated in the tissue were determined by the low temperature ashing-atomic absorption method ${ }^{5), 8}$. Further, to examine the behavior of the metals added to the reaction solution, a blank experiment was performed in which the endogenous metal contents in the intestine were found, then the real content of each metal was obtained by subtracting the endogenous content from the apparent content of each metal.

3. Gel filtration of intestinal mucosal supernatant fraction

After fasting, the rats were sacrificed. A piece of small intestine about $25 \mathrm{~cm}$ in length was cut from the duodenal intestine and incised, the contents being washed out with cold physiological saline solution, Then, the mucosa of the gut was scraped off with a cover glass and homogenized with 5 volumes of ice-cold $0.25 \mathrm{M}$ sucrose solution. The homogenate was ultracentrifuged at $105,000 \times g$ for $60 \mathrm{~min}$. Then $3 \mathrm{ml}$ of the supernatant fraction was applied to a Sephadex G-75 gel filtration column $(\phi 2.0 \times 60$ $\mathrm{cm}$ ) and eluted with $0.01 M$ Tris-hydrochloric acid buffer, $\mathrm{pH} 7.4$, at $30 \mathrm{ml} / \mathrm{hr}$. Fractions of $5 \mathrm{ml}$ were collected.

4. Measurement of ceruloplasmin $(C P)$ activity and $\mathrm{Cu}$ content in rat sera

Serum CP activity was measured by the method using Bandrowski base as a standard substance ${ }^{7), 8)}$, and serum $\mathrm{Cu}$ content by the direct atomic absorption method after dilution of the serum $1 / 10$ with $0.5 N$ nitric acid.

\section{Results}

\section{Effects of $\mathrm{Cd}$ on intestinal absorption of $\mathrm{Cu}$}

When $\mathrm{Cu}$ concentration in mucosal medium was set at $0.1 \mathrm{mM}$ and the medium was incubated for $60 \mathrm{~min}$, the $\mathrm{Cu}$ concentration in serosal medium of the Cd-administered intestine was about less than half that of the control. When the mucosal medium was incubated with Cys at 20 times the molar concentration of $\mathrm{Cu}$, the $\mathrm{Cu}$ concentration in the serosal medium was nearly the same as that obtained without Cys, in both the Cd-administered intestine and the control. The accumulated $\mathrm{Cu}$ content in the small intestinal tissue of the Cd-administered intestine decreased to less than $1 / 2$ that in the control, irrespective of the addition of Cys (Table 1). 
Table 2. Effect of Cadmium on Zinc Transport and Accumulation in Rat Small Intestine

\begin{tabular}{cccc}
\hline \hline Rat small intestine & Mucosal medium & $\begin{array}{c}\text { Transported } \mathrm{Zn} \\
(\mu \mathrm{g} / \mathrm{ml} \text { serosal medium })\end{array}$ & $\begin{array}{c}\text { Accumulated } \mathrm{Zn} \\
(\mu \mathrm{g} / \mathrm{g} \text { wet tissue })\end{array}$ \\
\hline $\mathrm{Cd}$ & $0.2 \mathrm{mM} \mathrm{Zn}$ & $1.8 \pm 0.4^{*}$ & $79.7 \pm 21.2^{*}$ \\
Control & $0.2 \mathrm{mMZn}$ & $7.0 \pm 1.8$ & $241.6 \pm 46.9$ \\
\hline $\mathrm{Cd}$ & $0.2 \mathrm{mMZn}+4.0 \mathrm{mM}$ Cys & $7.0 \pm 2.1^{*}$ & $76.7 \pm 13.7^{*}$ \\
Control & $0.2 \mathrm{mMZn}+4.0 \mathrm{mM}$ Cys & $15.1 \pm 3.2$ & $202.7 \pm 31.5$ \\
\hline
\end{tabular}

The everted sac was incubated in mucosal medium at $37^{\circ} \mathrm{C}$ for $60 \mathrm{~min}$.

$\mathrm{Cd}: \mathrm{CdCl}_{2} \cdot 2.5 \mathrm{H}_{2} \mathrm{O}(80 \mathrm{mg} / \mathrm{kg} /$ day $)$ for 4 weeks

Control: Distilled water

Each value is the mean \pm S.D. for 5 intestines.

$* p<0.05$ from Control

Table 3. Effect of Cadmium on Iron Transport and Accumulation in Rat Small Intestine

\begin{tabular}{cccc}
\hline \hline Rat small intestine & Mucosal medium & $\begin{array}{c}\text { Transported Fe } \\
(\mu \mathrm{g} / \mathrm{ml} \text { serosal medium })\end{array}$ & $\begin{array}{c}\text { Accumulated Fe } \\
(\mu \mathrm{g} / \mathrm{g} \text { wet tissue })\end{array}$ \\
\hline Cd & $0.2 \mathrm{mMFe}$ & $0.15 \pm 0.09^{*}$ & $36.3 \pm 4.6^{*}$ \\
Control & $0.2 \mathrm{mMFe}$ & $0.44 \pm 0.15$ & $102.3 \pm 9.4$ \\
\hline Cd & $0.2 \mathrm{mMFe}+4.0 \mathrm{mM}$ Cys & $7.2 \pm 1.3^{*}$ & $39.5 \pm 8.3^{*}$ \\
Control & $0.2 \mathrm{mMFe}+4.0 \mathrm{mM}$ Cys & $17.0 \pm 1.7$ & $121.0 \pm 15.7$ \\
\hline
\end{tabular}

The everted sac was incubated in mucosal medium at $37^{\circ} \mathrm{C}$ for $60 \mathrm{~min}$.

$\mathrm{Cd}: \mathrm{CdCl}_{2} \cdot 2.5 \mathrm{H}_{2} \mathrm{O}(80 \mathrm{mg} / \mathrm{kg} /$ day $)$ for 4 weeks

Control: Distilled water

Each value is the mean \pm S.D. for 5 intestines.

$* p<0.05$ from Control

2. Effects of $C d$ on intestinal absorption of $Z n$

When the mucosal medium was incubated at a $\mathrm{Zn}$ concentration of $0.2 \mathrm{mM}$ for $60 \mathrm{~min}$, the $\mathrm{Zn}$ concentration in serosal medium of the Cdadministered intestine decreased to about $1 / 4$ that of the control. After incubation with the addition of Cys, the amount of transported $\mathrm{Zn}$ increased about 4 times in the Cd-administered intestine, and about 2 times in the control as compared with the non-addition of Cys. However, the amount of transported $\mathrm{Zn}$ in the $\mathrm{Cd}$ administered intestine was approximately $1 / 2$ that in the control. The content of accumulated $\mathrm{Zn}$ in the small intestinal tissue of the $\mathrm{Cd}$ administered intestine decreased to about $1 / 3$ that in the control, irrespective of the addition of Cys (Table 2).

3. Effects of $\mathrm{Cd}$ on intestinal absorption of $\mathrm{Fe}$

When the mucosal medium was incubated at an $\mathrm{Fe}$ concentration of $0.2 \mathrm{mM}$ for $60 \mathrm{~min}$ with and without Cys, the amount of transported $\mathrm{Fe}$ varied as seen in the case of $\mathrm{Zn}$. The amounts of accumulated $\mathrm{Fe}$ in the small intestinal tissue with and without Cys also varied as observed

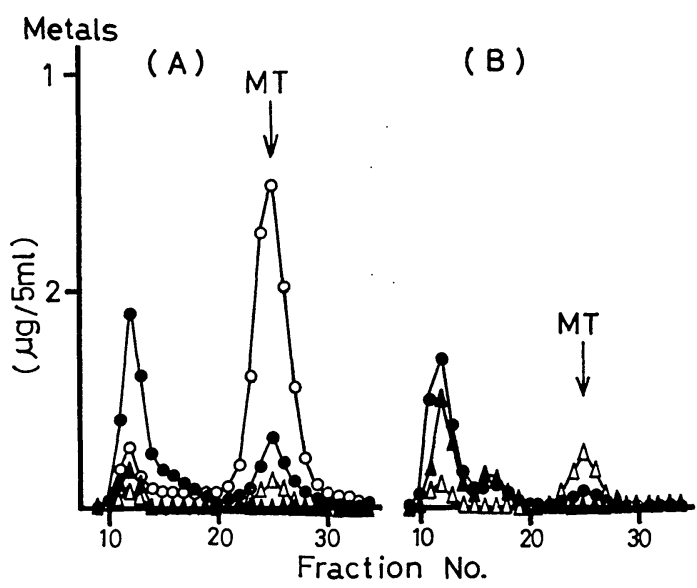

Fig. 1. Sephadex G-75 gel filtration of intestinal mucosa supernatant after repeated oral administration for 4 weeks

(A): $\mathrm{CdCl}_{2} \cdot 2.5 \mathrm{H}_{2} \mathrm{O}(80 \mathrm{mg} / \mathrm{kg})$

(B): control $\left(\mathrm{H}_{2} \mathrm{O}\right)$

-O-: $\mathrm{Cd}$; -O-: $\mathrm{Zn}$

$-\triangle-: \mathrm{Cu} ;-\Delta-\mathrm{Fe}$ 
Table 4. Ceruloplasmin Activity and Cu Content in Rat Sera After Repeated Oral Administration of Cd and L-Cysteine for 4 Weeks

\begin{tabular}{ccccc}
\hline & $\mathrm{Cd}$ & $\mathrm{Cd}+\mathrm{Cys}$ & Control & Cys \\
\hline Ceruloplasmin $(\mathrm{mU} / \mathrm{ml})$ & $24.0 \pm 9.0^{*}$ & $71.0 \pm 22.4^{* *}$ & $80.3 \pm 5.1$ & $88.6 \pm 9.3$ \\
$\mathrm{Cu}(\mu \mathrm{g} / \mathrm{ml})$ & $0.39 \pm 0.15^{*}$ & $1.10 \pm 0.31^{* *}$ & $1.41 \pm 0.06$ & $1.35 \pm 0.11$ \\
\hline
\end{tabular}

$\mathrm{Cd}: \mathrm{CdCl}_{2} \cdot 2.5 \mathrm{H}_{2} \mathrm{O}(80 \mathrm{mg} / \mathrm{kg}) ; \mathrm{Cd}+\mathrm{Cys}: \mathrm{CdCl}_{2} \cdot 2.5 \mathrm{H}_{2} \mathrm{O}(80 \mathrm{mg} / \mathrm{kg})+$ cysteine $\cdot \mathrm{HCl}(1,500 \mathrm{mg} / \mathrm{kg})$

Control: distilled water; Cys: cysteine $\cdot \mathrm{HCl}(1,500 \mathrm{mg} / \mathrm{kg})$

Each value is the mean \pm S.D. for 5 rats.

$* p<0.05$ from control

** $p<0.05$ from $\mathrm{Cd}$

in the case of $\mathrm{Zn}$ (Table 3).

4. Gel filtration of intestinal mucosal supernatant fraction

The intestinal mucosal supernatant fraction from the rats administered $\mathrm{Cd}$ alone for 4 weeks was subjected to Sephadex G-75 gel filtration to examine the distribution of metals (Fig. 1).

Most of the $\mathrm{Cd}$ in the supernatant fraction was present in the metallothionein (MT) fraction. $\mathrm{Cu}$ was not as extensively distributed in the MT fraction as in the case of the control, while $\mathrm{Zn}$ was increased in the MT fraction. Fe was decreased in the high molecular fraction (apoferritin fraction) as compared with the control. 5. $C P$ activity and $C u$ content in sera after repeated oral administration

Serum $\mathrm{CP}$ activity and $\mathrm{Cu}$ content were examined in four groups orally given $\mathrm{Cd}$ only, $\mathrm{Cd}$ plus Cys, distilled water and Cys only for 4 consecutive weeks (Table 4).

The Cd group showed significantly low CP activity and $\mathrm{Cu}$ content as compared with the control group, while the $\mathrm{Cd}$ plus $\mathrm{Cys}$ group showed slightly (but not significantly) lower CP activity and $\mathrm{Cu}$ content as compared with the Cys group.

\section{Discussion}

In the previous reports ${ }^{1,2)}$, it was proved that $\mathrm{Cd}$ greatly affected the fates of $\mathrm{Cu}, \mathrm{Zn}$ and $\mathrm{Fe}$. In particular, the $\mathrm{Cu}$ and $\mathrm{Fe}$ contents in organs decreased as compared with the control value. It was also found that the simultaneous administration of Cys with Cd suppressed such decreases in $\mathrm{Cu}$ and $\mathrm{Fe}$ contents. We supposed that these phenomena might occur at the intestinal absorption level, and so we performed the present study to examine this hypothesis in an in vitro experiment using rat everted intestine. Although there are many reports on the transport capabilities of calcium ${ }^{4)}$ and $\mathrm{Cd}^{9) \sim 11)}$ in everted intestine, little is known about the transport capabilities of $\mathrm{Cu}, \mathrm{Zn}$ and $\mathrm{Fe}$.

As regards the effects of $\mathrm{Cd}$ on intestinal $\mathrm{Cu}$ absorption, Cd clearly inhibited $\mathrm{Cu}$ absorption, but Cys did not promote $\mathrm{Cu}$ absorption (Table 1). The former result is consistent with the previous finding ${ }^{1)}$ that oral administration of $\mathrm{Cd}$ decreased the $\mathrm{Cu}$ content in organs as compared with the control. The latter is not consistent with the previous finding that the simultaneous administration of Cys with $\mathrm{Cd}$ suppressed such a decrease in $\mathrm{Cu}$ content. Thus, serum $\mathrm{CP}$ activity and $\mathrm{Cu}$ content were examined in rats orally administered $\mathrm{Cd}$ only, $\mathrm{Cd}$ plus Cys, distilled water and Cys only for 4 consecutive weeks. The results indicated inhibition of $\mathrm{Cu}$ absorption by the administration of $\mathrm{Cd}$ and promotion of $\mathrm{Cu}$ absorption by the simultaneous administration of Cys with Cd (Table 4). Accordingly, it seems that the in vitro experimental results do not reflect the in vivo findings. Very little is known about the intestinal absorption of $\mathrm{Cu}$. Kojima et al. ${ }^{10)}$ reported that the higher the stability constant of an amino acid with $\mathrm{Cd}$, the better the amino acid promotes intestinal transport of $\mathrm{Cd}$. The stability constant between Cys and $\mathrm{Cu}$ is 19.2, which is far higher than that of $\mathrm{Fe}$ (6.2) and ranks with that of $\mathrm{Zn}$ (18.7). Therefore, it seemed that intestinal transport of $\mathrm{Cu}$ was promoted by Cys in the same way as in the cases of $\mathrm{Zn}$ and $\mathrm{Fe}$ (Tables 2 and 3). However, the in vitro experimental results did not accord with this supposition. There is evidence of an active transport system for $\mathrm{Cu}$ which presumably exists at the membrane on the serosal aspect of the cell. ${ }^{12)}$ Possibly Cys did 
not promote the transport of $\mathrm{Cu}$ because an active transport process was not produced in consequence of the use of the everted intestine system in vitro.

As regards the effects of $\mathrm{Cd}$ on intestinal $\mathrm{Zn}$ and $\mathrm{Fe}$ absorptions, $\mathrm{Cd}$ evidently inhibited both $\mathrm{Zn}$ and $\mathrm{Fe}$ absorptions. Cys markedly promoted both $\mathrm{Zn}$ and $\mathrm{Fe}$ absorptions (Tables 2 and 3 ). The results concerning $\mathrm{Zn}$ in this study are consistent with the supposition based on the previous findings ${ }^{1)}$ that the $\mathrm{Zn}$ content in organs is increased rapidly by oral administration of $\mathrm{Cd}$, then gradually decreased. Therefore, $\mathrm{Cd}$ may inhibit $\mathrm{Zn}$ absorption. Further, the $\mathrm{Zn}$ content in organs was not decreased whereas the $\mathrm{Zn}$ content in urine was increased by Cys, so that Cys may promote $\mathrm{Zn}$ absorption. With regard to $\mathrm{Fe}$, the results of this study are consistent with the previous findings ${ }^{2)}$ that the $\mathrm{Fe}$ content in organs was markedly decreased by oral administration of $\mathrm{Cd}$ as compared with the control value, and that such a decrease in $\mathrm{Fe}$ content was suppressed by the simultaneous administration of Cys with $\mathrm{Cd}$.

The data indicated that $\mathrm{Cd}$ inhibited $\mathrm{Cu}, \mathrm{Zn}$ and $\mathrm{Fe}$ transports, because the amounts of metals $(\mathrm{Cu}, \mathrm{Zn}$ and $\mathrm{Fe}$ ) absorbed or adsorbed on the Cd-administered rat intestine were evidently lower than those in the control, and accordingly, the amounts of transported metals were probably decreased. In the gel filtration profile of the intestinal mucosal supernatant fraction shown in Fig. 1, a large portion of Cd is observed in the MT fraction in the Cd-administered rats. Based on the mean weight of the everted sacs (each about $5-6 \mathrm{~cm}$ in length), $0.605 \mathrm{~g}$ for Cd-administered intestine and $0.380 \mathrm{~g}$ for controls, it was apparent that $\mathrm{Cd}$-administered intestine did thicken or enlarge. As a related matter, it has been reported that the intestinal function was impaired by $\mathrm{Cd}^{13), 14)}$. This may explain why the absorption or adsorption of metals $(\mathrm{Cu}, \mathrm{Zn}$ and $\mathrm{Fe})$ on $\mathrm{Cd}$-administered intestine was apparently decreased as compared with that of the control.

Kojima et al. ${ }^{9), 10)}$ reported that coexistence of a chelating agent such as EDTA, L-cysteine, Lhistidine or other amino acids promoted intestinal $\mathrm{Cd}$ absorption. The reason was supposed to be that $\mathrm{Cd}$ might pass through the epithelial cells of the intestinal mucosa after forming a stable compound with a chelator. In this study as well, coexistence of Cys increased intestinal absorptions of both $\mathrm{Zn}$ and $\mathrm{Fe}$, presumably through a mechanism similar to that proposed by Kojima et al. .

Many studies have been carried out on the interaction between $\mathrm{Cd}$ and other metals $(\mathrm{Cu}$, $\mathrm{Zn}$ and $\mathrm{Fe}$ ), especially on the effects of $\mathrm{Cd}$ on intestinal absorption of essential metals, and the inhibition of intestinal $\mathrm{Zn}$ and $\mathrm{Fe}$ absorptions by $\mathrm{Cd}$ has been suggested by in vivo ${ }^{15), 18)}$ and in $s_{\left.i t u^{17}\right)}$ experiments. Similar results were obtained from our in vitro experiment using rat everted intestine. Thus, this experimental system should be very useful for studies on intestinal absorption and on the fates of $\mathrm{Cu}, \mathrm{Zn}$ and $\mathrm{Fe}$ after oral administration of $\mathrm{Cd}$.

\section{References}

1) Tanaka, Y., Tanaka, R., Kashimoto, T.: J. Food Hyg. Soc. Japan 26, 411 422 (1985).

2) Tanaka, Y., Tanaka, R., Kashimoto, T.: ibid. 26, 423 431 (1985).

3) Japanese Biological Society, Ed.: "Seikagaku Jikkenkoza, Volume 13 (low volume)" p. 611 615 (1975) Tokyo Kagaku Dojin Ltd., Tokyo, Japan (in Japanese).

4) Martin, D. L., DeLuca, H. F.: Am. J. Physiol. 216, 1351 1359 (1969).

5) Tanaka, Y., Tanaka, R., Kashimoto, T.: J. Food Hyg. Soc. Japan 21, 366 372 (1980) (in Japanese).

6) Tanaka, R., Ikebe, K., Tanaka, Y., Kashimoto, T.: ibid. 24, 136 141 (1983).

7) Ravin, H. A.: J. Lab \& Clin. Med. 58, 161 168 (1961).

8) Rice, E. W.: Clin. Chim. Acta 5, 632 636 (1960).

9) Kojima, S., Kiyozumi, M.: Yakugaku Zasshi 94, 695 701 (1974) (in Japanese).

10) Kojima, S., Kiyozumi, M., Kamiya, M.: J. Food Hyg. Soc. Japan 19, 553 558 (1978).

11) Kojima, S., Kiyozumi, M., Mishima, M., Aburaya, K., Furuya, K.: Eisei Kagaku 26, 267 271 (1980).

12) Danks, D. M., Cartwright, E., Stevens, B. J., Townley, R. R. W.: Science 179, 1140 1142 (1973).

13) Suda, T., Suzuki, M., Fujii, K., Sasaki, T., Yoshiki, S.: Kotsutaisha 7, 65 71 (1973) (in Japanese).

14) Sugawara, C., Sugawara, N.: Jpn. J. Hyg. 28, $511 \sim 516$ (1974) (in Japanese). 
15) Hahn, C. J., Evans, G. W.: Am. J. Physiol. 228, 1020 1023 (1975).

16) Evans, G. W., Grace, C. I., Hahn, C. J.:
Bioinorganic Chem. 3, 115 120 (1974).

17) Hamilton, D. L., Valberg, L. S.: Am. J. Physiol. 227, 1033 1037 (1974). 